University of South Florida

DIGITAL COMMONS

Digital Commons @ University of

@ UNIVERSITY OF SOUTH FLORIDA

South Florida

USF St. Petersburg campus Faculty

Publications

USF Faculty Publications

2007

\title{
Support for Research and Service in Florida Academic Libraries
}

Tina M. Neville

neville@mail.usf.edu

Deborah Boran Henry

henry@mail.usf.edu

Follow this and additional works at: https://digitalcommons.usf.edu/fac_publications

Part of the Library and Information Science Commons

\section{Recommended Citation}

Neville, T. M., \& Henry, D. B. (2007). Support for research and service in Florida academic libraries. The Journal of Academic Librarianship, 33(1), 76-93. doi: 10.1016/j.acalib.2006.06.003

This Article is brought to you for free and open access by the USF Faculty Publications at Digital Commons @ University of South Florida. It has been accepted for inclusion in USF St. Petersburg campus Faculty Publications by an authorized administrator of Digital Commons @ University of South Florida. For more information, please contact digitalcommons@usf.edu. 
Support for Research and Service in Florida Academic Libraries

by

Tina M. Neville and Deborah B. Henry

Nelson Poynter Memorial Library,

University of South Florida St. Petersburg

neville@nelson.usf.edu

henry@nelson.usf.edu 


\begin{abstract}
Following a 2003 survey that benchmarked the research and publication activities of Florida librarians, administrative support for these efforts was investigated. Library administrators were asked to identify various types and funding levels of travel and research assistance. Results suggest that Florida librarians receive support comparable to national and regional trends.
\end{abstract}

\title{
Introduction
}

Faculty status and the research productivity of librarians comprise a significant portion of the academic library literature. As early as 1911, Columbia University accorded its librarians faculty status. ${ }^{1}$ Robert Downs, a pioneer in the faculty status issue, encouraged academic librarians in 1957 to work for professional achievements on the same levels as the teaching faculty. ${ }^{2}$ The faculty debate gained momentum with the 1971 adoption of the Association of College and Research Libraries (ACRL) Standards for Faculty Status for College and University Librarians. ${ }^{3}$ These standards set forth criteria for providing the same rights and privileges to library faculty as those already enjoyed by the teaching faculty.

But are librarians really receiving the same privileges and support for research that teaching faculty receive? Research support is not inexpensive. Kingma and McCombs endeavored to put a dollar figure on the opportunity cost of faculty status for librarians. Looking beyond the actual costs of travel and directed research funds, the authors attempted to calculate the costs of intangibles such as the time it takes library faculty to pursue their own research or the time spent peer reviewing others' scholarship. ${ }^{4}$ 
Havener and Stolt analyzed publications of academic librarians in Oklahoma for the year 1990. They found that librarians working at institutions that supported research had much better publication records than those employed at institutions that did not provide support for research. ${ }^{5}$

Although many articles have been written on this topic since publication of the 1971 Standards, the large majority of the studies concentrate on the pros and cons of faculty status for librarians. During the fall of 2003, the authors conducted a web survey of academic librarians in Florida. The goal of this survey was to establish benchmarks for research productivity and professional development activities and explore the relationships of those activities to tenure and promotion or to professional development. ${ }^{6}$ The perception of many of the responding librarians was that expectations were continually increasing for research productivity. The results of the survey led the authors to investigate if academic institutions were providing support commensurate with the demand for greater professional productivity. Are academic librarians getting the time and funding needed to realistically conduct scholarly research? What methods, beyond release time and research funds, have institutions developed to help their librarians succeed in publishing?

Havener and Worrell point out that some national studies or surveys that concentrate on Association of Research Libraries (ARL) institutions may not give a complete picture of the status of academic librarians since these studies are skewed towards larger, research-oriented institutions. They advocate the need for more statelevel studies. ${ }^{7}$ This project surveyed library administrators in academic institutions throughout Florida to document the level of support available for research and professional activities of librarians. Because research support may be expensive, reasonable benchmarks for this area are needed. Reporting on the level of research 
assistance in Florida may also aid institutions here and elsewhere in evaluating, implementing, and/or maintaining support programs for research and scholarly activities conducted by academic librarians.

\section{Literature Review}

Relatively little has been published on the availability of support for research, travel, release time, and sabbaticals. Many of the studies that have been conducted are dated or are concentrated on ARL libraries. ${ }^{8}$ Libraries in the southeastern United States have also been studied in some detail. ${ }^{9} \quad$ In 1958, Boughter compared sabbatical opportunities for library faculty to the opportunities for teaching faculty at the same institutions. ${ }^{10}$ Several other authors have found that sabbaticals were offered at some institutions but not always at the same levels as those allowed for teaching faculty. ${ }^{11}$ In addition, while extended leave time may be available in theory, some librarians feel that staffing shortages within the library make taking a sabbatical unrealistic. ${ }^{12}$

In 1966, ARL library directors were already expressing concern over how to balance time for research while still retaining good service to the public. ${ }^{13}$ A few studies have looked at the amount of time per week that librarians and teaching faculty allocate to research activities. ${ }^{14}$ As might be expected, studies of teaching faculty indicate that much of their research is conducted during the summer when teaching loads are normally

lighter. ${ }^{15}$ Librarians on twelve month contracts don't have summer research options. Although librarians often express frustration over the lack of flexibility within their work schedule, making it difficult to fit in focused research time, similar concerns are expressed by teaching faculty, particularly those with heavy teaching loads at predominantly undergraduate institutions. ${ }^{16}$ Sharobeam and Howard contend that sporadic attempts at research can be costly_-both for the time needed to reorganize the 
researcher's thoughts but also in potential loss of readership if a topic is no longer timely. $^{17}$

While many academic institutions expect their faculty to apply for external funding for their research, some colleges and universities also provide small internal grants to researchers. Several studies indicate that librarians do qualify to request research funding from their institutions but with varying levels of success. A survey of librarians and teaching faculty in Michigan, Minnesota, and Wisconsin colleges and universities reported that although librarians were allowed to apply for research funds, they did not receive the same level of support as the teaching faculty. ${ }^{18}$ The research status of the institution may also play a role in support for research. In 1996, Leysen and Black surveyed library administrators at Carnegie Research I and II institutions ${ }^{19}$ finding that institutional funding was available for the majority of the librarians who had faculty status with publishing as a requirement for tenure..$^{20}$

Funding for travel may be another important component of research support. Not only do librarians gain new insights by attending and presenting at professional conferences, some types of research may require traveling to gather data, to learn new procedures or systems, or to gain access to unique collections. Henry and Neville's survey of Florida academic librarians found that slightly more than half of the respondents received full travel support for their professional activities. Only a small number claimed that they did not have any travel funding available to them. ${ }^{21}$ Blomberg and Chapman's 1989 study of ARL libraries provides very specific details on what aspects of travel (lodging, conference registration, etc.) were most likely to be funded. ${ }^{22}$ In the same year, Cramer analyzed how travel funds were obtained at ARL libraries. ${ }^{23}$

Professional associations' conferences and publications provide mechanisms for the exchange of ideas and for the creation of new research. Unfortunately, it is not 
unusual to hear librarians claim that the membership fees of state, regional, and national associations prohibit them from joining or require them to be very selective about the number of associations that they join. In fact, editorials by library professionals and minutes from library associations document concerns over the rising cost of membership dues and conference attendance and the impact these increases may have on newer and lower-paid librarians. ${ }^{24}$ A few institutions are supporting librarian's participation in professional associations by reimbursing them for their membership dues. ${ }^{25}$

Research time, travel, and financial support are all standard methods for supporting research at academic institutions. Several libraries have tried additional approaches for increasing the research productivity of their librarians through the creation of more flexible work schedules, formal or informal mentoring, or the creation of research committees.

\section{Methodology}

This study expands on the research support issues that were discussed in a 2003 survey of Florida academic librarians. ${ }^{26}$ Survey questions were sent to library administrators at academic institutions in Florida and addressed specific details on research time, funding, and support available to librarians at their institutions. Florida libraries were selected for this survey to provide direct comparisons with the authors' previous survey. Professional leave times (sabbaticals, release time, etc.) were defined in the survey in order to facilitate the analysis of the results and comparisons to other data. The survey examined what types of travel are funded, the sources of those funds, and how the funds are approved. Finally, participants were asked about creative methods that they may have found to help librarians be more productive in their research efforts. The 
authors created the survey instrument (included in Appendix 1) from prior surveys reported in the literature and from gaps in the library knowledge that were identified. ${ }^{27}$

Library administrators' names were collected from institutional web sites or from The American Library Directory. ${ }^{28}$ If institutions had regional campuses with separate, identifiable library administrators, they were sent a separate survey. Administrators were asked to respond to the survey personally or to give it to another library administrator who might be more suited to answer the questions. Participants were also given the opportunity to make additional comments. Several professional colleagues reviewed the survey for clarity and ease of use prior to distribution. The University of South Florida Institutional Research Board ensured that human research and anonymity issues were acceptable.

Surveys were mailed to ninety-two library directors in early May 2005. A stamped, self-addressed envelope was included for ease of return. After approximately three weeks, reminder notices were sent to institutions that had not responded. A final email reminder was sent to non-respondents in June 2005. Survey responses were recorded in a database for analysis. Institutions were coded by Carnegie Classification in order to organize the institutions by type and to provide direct comparisons with the authors' previous survey. ${ }^{29}$

\section{Results}

Although sixty-nine administrators responded in some way to the survey, the data from sixty-five were usable for a response rate of $71 \%$. The distribution of responding institutions according to Carnegie classification and the initial total population is very similar (Table 1). In the discussion that follows, sample sizes are included and percentages are rounded to the nearest whole number. 
Table 1

Carnegie Classification of Florida SACS Accredited Institutions*

\begin{tabular}{|c|c|c|}
\hline & $\begin{array}{c}\text { Number of institutions in } \\
\text { original population }\end{array}$ & $\begin{array}{l}\text { Percent within Carnegie } \\
\text { Class responding to survey }\end{array}$ \\
\hline Associate Colleges & 38 & $\begin{array}{c}61 \% \\
(n=23)\end{array}$ \\
\hline $\begin{array}{l}\text { Baccalaureate Colleges- } \\
\text { General }\end{array}$ & 9 & $\begin{array}{l}56 \% \\
(n=5)\end{array}$ \\
\hline $\begin{array}{l}\text { Baccalaureate Colleges- } \\
\text { Liberal Arts }\end{array}$ & 3 & $\begin{array}{l}67 \% \\
(n=2)\end{array}$ \\
\hline $\begin{array}{l}\text { Master's Colleges and } \\
\text { Universities I }\end{array}$ & 15 & $\begin{array}{c}87 \% \\
(n=13)\end{array}$ \\
\hline $\begin{array}{l}\text { Master's Colleges and } \\
\text { Universities II }\end{array}$ & 2 & $\begin{array}{l}50 \% \\
(\mathrm{n}=1)\end{array}$ \\
\hline $\begin{array}{l}\text { Doctoral/Research } \\
\text { Universities-Intensive }\end{array}$ & 6 & $\begin{array}{l}100 \% \\
(n=6)\end{array}$ \\
\hline $\begin{array}{l}\text { Doctoral/Research } \\
\text { Universities-Extensive }\end{array}$ & 13 & $\begin{array}{c}85 \% \\
(\mathrm{n}=11)\end{array}$ \\
\hline Specialized Institutions & 5 & $\begin{array}{l}60 \% \\
(n=3)\end{array}$ \\
\hline Other-unable to classify & 1 & $\begin{array}{l}100 \% \\
(\mathrm{n}=1)\end{array}$ \\
\hline $\begin{array}{l}\text { Total institutions in this } \\
\text { study }\end{array}$ & 92 & \\
\hline
\end{tabular}


(faculty $73 \%$, professional $17 \%$ ). ${ }^{30}$ While only $29 \%$ (19 of 65 ) of the total academic libraries survey are covered by some kind of union contract or bargaining agreement; a higher percentage of doctoral institutions (47\%, 8 of 17) reported having bargaining agreements.

Table 2 illustrates the availability of promotion or tenure with $43 \%(n=28)$ of the libraries offering promotion, tenure and/or dual tracks to faculty at baccalaureate, master's, or doctoral institutions. An additional twenty institutions (31\%) offer a continuing contract or a contract with advancement opportunities. Requirements for advancement vary considerably and may include research, teaching, service, and/or continuing education achievements. Thirteen (20\%) of the library institutions have professionals who are not eligible for either promotion, tenure, or other continuing contracts.

Table 2

Eligibility for Promotion or Tenure

\begin{tabular}{lcc}
\hline & $\begin{array}{c}\text { Number of responses } \\
(\mathbf{n = 6 5})\end{array}$ & \% of responses \\
\hline Promotion and tenure & 7 & $11 \%$ \\
Promotion only & 17 & $26 \%$ \\
$\begin{array}{l}\text { Dual tracks: both tenure } \\
\text { track and promotion only } \\
\text { tracks available }\end{array}$ & 4 & $6 \%$ \\
$\begin{array}{l}\text { Continuing contract } \\
\text { Continuing contract and } \\
\text { promotion }\end{array}$ & 11 & $17 \%$ \\
$\begin{array}{l}\text { Not eligible for promotion } \\
\text { or tenure }\end{array}$ & 9 & $14 \%$ \\
Other & 13 & $20 \%$ \\
$\quad$ Total & 4 & $6 \%$ \\
& 65 & $100 \%$
\end{tabular}


The library administrators were asked to indicate if they felt that promotion and/or tenure requirements had become more rigorous, less difficult, or stayed about the same during the last five years. Forty-nine percent believe the criteria for advancement are more rigorous, only $5 \%$ felt the process was less rigorous and $42 \%$ replied that the criteria were the same or had no opinion. In 2003, a similar question was asked of practicing academic librarians in Florida. At that time librarians on tenure tracks $(83 \%)$ or on promotion-only tracks $(65 \%)$ definitely felt the requirements had become more demanding. ${ }^{31}$ Although the administrators at tenure-track institutions agreed with their library faculty that the emphasis on publishing was increasing, the administrators at promotion-earning institutions were not as convinced with only $41 \%$ of those administrators claiming a greater emphasis on publishing (Table 3).

The current survey also examined the chain of command in tenure and promotion processes. The procedure at $66 \%$ (33 of 50) of the institutions requires multiple stages of approval. Not unexpectedly, approvals by a library supervisor/director and/or the institution's administration are the two most common steps 66\% (33 of 50) in the process. A peer review committee is used by 54\% (27 of 50) of the organizations.

\section{Travel}

The majority of organizations $(95 \%, 60$ of 63$)$ provide some level of travel support. Fifty-one percent reported that the level of support has remained constant over the last five years while 37\% have received an increase in support. As seen in Table 4, doctoral and baccalaureate libraries have seen the largest increases. The approval process for travel benefits varies; in $87 \%$ (52 of 60) of the libraries, the library Dean or Director approves the request, while $32 \%$ (19 of 60) of the organizations employ a multiple step approval process. A campus-wide administrative body participates in the process at 
Table 3

Perceptions of Respondents of the Emphasis on Publishing for Promotion and Tenure* Comparisons of 2003 and 2005 Survey Data

\begin{tabular}{|c|c|c|c|c|c|}
\hline & $\begin{array}{c}\text { Greater } \\
\text { Emphasis }\end{array}$ & $\begin{array}{l}\text { Lesser } \\
\text { Emphasis }\end{array}$ & $\begin{array}{l}\text { No change in } \\
\text { Emphasis }\end{array}$ & $\begin{array}{l}\text { No Opinion on } \\
\text { Emphasis }\end{array}$ & $\begin{array}{l}\text { Emphasis Not } \\
\text { Applicable to } \\
\text { Circumstances }\end{array}$ \\
\hline $\begin{array}{l}2005 \text { Tenure-track } \\
\text { (Baccalaureate, Master's or } \\
\text { Doctoral) } \\
\text { (total responses }=10 \text { ) }\end{array}$ & $\begin{array}{l}100 \% \\
(\mathrm{n}=10)\end{array}$ & $\begin{array}{c}0 \% \\
(\mathrm{n}=0)\end{array}$ & $\begin{array}{c}0 \% \\
(\mathrm{n}=0)\end{array}$ & $\begin{array}{c}0 \% \\
(\mathrm{n}=0)\end{array}$ & $\begin{array}{c}0 \% \\
(\mathrm{n}=0)\end{array}$ \\
\hline $\begin{array}{l}2003 \text { Tenure-track } \\
\text { (Baccalaureate, Master's or } \\
\text { Doctoral) } \\
\text { (total responses }=36 \text { ) }\end{array}$ & $\begin{array}{c}83 \% \\
(n=30)\end{array}$ & $\begin{array}{c}8 \% \\
(\mathrm{n}=3)\end{array}$ & $\begin{array}{c}8 \% \\
(\mathrm{n}=3)\end{array}$ & $\begin{array}{c}0 \% \\
(\mathrm{n}=0)\end{array}$ & $\begin{array}{c}0 \% \\
(\mathrm{n}=0)\end{array}$ \\
\hline $\begin{array}{l}2005 \text { Promotion-earning (all } \\
\text { institutions) } \\
\text { (total responses }=17 \text { ) }\end{array}$ & $\begin{array}{l}41 \% \\
(n=7)\end{array}$ & $\begin{array}{l}12 \% \\
(\mathrm{n}=2)\end{array}$ & $\begin{array}{l}35 \% \\
(n=6)\end{array}$ & $\begin{array}{l}12 \% \\
(n=2)\end{array}$ & $\begin{array}{c}0 \% \\
(\mathrm{n}=0)\end{array}$ \\
\hline $\begin{array}{l}2003 \text { Promotion-earning (all } \\
\text { institutions) } \\
\text { (total responses }=69 \text { ) }\end{array}$ & $\begin{array}{c}65 \% \\
(n=45)\end{array}$ & $\begin{array}{c}25 \% \\
(\mathrm{n}=17)\end{array}$ & $\begin{array}{c}6 \% \\
(n=4)\end{array}$ & $\begin{array}{c}3 \% \\
(\mathrm{n}=2)\end{array}$ & $\begin{array}{c}1 \% \\
(n=1)\end{array}$ \\
\hline $\begin{array}{l}2005 \text { Tenure/Continuing } \\
\text { Contract (Community Colleges) } \\
\text { (total responses }=13 \text { ) }\end{array}$ & $\begin{array}{l}23 \% \\
(\mathrm{n}=3)\end{array}$ & $\begin{array}{c}0 \% \\
(\mathrm{n}=0)\end{array}$ & $\begin{array}{l}38 \% \\
(\mathrm{n}=5)\end{array}$ & $\begin{array}{l}38 \% \\
(\mathrm{n}=5)\end{array}$ & $\begin{array}{c}0 \% \\
(\mathrm{n}=0)\end{array}$ \\
\hline $\begin{array}{l}2003 \text { Tenure/Continuing } \\
\text { Contract (Community Colleges) } \\
\text { (total responses }=31 \text { ) }\end{array}$ & $\begin{array}{l}23 \% \\
(n=7)\end{array}$ & $\begin{array}{c}39 \% \\
(\mathrm{n}=12)\end{array}$ & $\begin{array}{l}10 \% \\
(\mathrm{n}=3)\end{array}$ & $\begin{array}{c}6 \% \\
(\mathrm{n}=2)\end{array}$ & $\begin{array}{l}23 \% \\
(n=7)\end{array}$ \\
\hline $\begin{array}{l}\text { 2005 Total Institutions } \\
\text { (total responses }=45)^{* * *}\end{array}$ & $\begin{array}{c}44 \% \\
(n=20)\end{array}$ & $\begin{array}{c}4 \% \\
(\mathrm{n}=2)\end{array}$ & $\begin{array}{c}24 \% \\
(\mathrm{n}=11)\end{array}$ & $\begin{array}{l}18 \% \\
(\mathrm{n}=8)\end{array}$ & $\begin{array}{c}9 \% \\
(\mathrm{n}=4)\end{array}$ \\
\hline $\begin{array}{l}2003 \text { Total Institutions } \\
\text { (total responses=136) }\end{array}$ & $\begin{array}{c}60 \% \\
(\mathrm{n}=82)\end{array}$ & $\begin{array}{c}24 \% \\
(\mathrm{n}=32)\end{array}$ & $\begin{array}{c}7 \% \\
(\mathrm{n}=10)\end{array}$ & $\begin{array}{c}3 \% \\
(n=4)\end{array}$ & $\begin{array}{c}6 \% \\
(n=8)\end{array}$ \\
\hline
\end{tabular}


Table 4

Level of Travel Funding Over the Past 5 Years*

\begin{tabular}{|c|c|c|c|}
\hline & $\begin{array}{c}\text { Funding Increased } \\
\text { During the Past } 5 \\
\text { Years }\end{array}$ & $\begin{array}{c}\text { Funding } \\
\text { Decreased } \\
\text { During the Past } \\
5 \text { Years } \\
\end{array}$ & $\begin{array}{c}\text { Funding Stayed } \\
\text { About the Same } \\
\text { During the Past } \\
5 \text { Years } \\
\end{array}$ \\
\hline $\begin{array}{l}\text { Doctoral/Research: } \\
\text { Extensive and Intensive } \\
\text { (total responses }=17 \text { ) }\end{array}$ & $\begin{array}{l}53 \% \\
(n=9)\end{array}$ & $\begin{array}{l}24 \% \\
(n=4)\end{array}$ & $\begin{array}{l}24 \% \\
(n=4)\end{array}$ \\
\hline $\begin{array}{l}\text { Master's Colleges and } \\
\text { Universities I and II } \\
\text { (total responses }=12 \text { ) }\end{array}$ & $\begin{array}{l}25 \% \\
(n=3)\end{array}$ & $\begin{array}{c}8 \% \\
(\mathrm{n}=1)\end{array}$ & $\begin{array}{l}67 \% \\
(n=8)\end{array}$ \\
\hline $\begin{array}{l}\text { Baccalaureate Colleges: } \\
\text { General and Liberal Arts } \\
\text { (total responses=6) }\end{array}$ & $\begin{array}{l}50 \% \\
(\mathrm{n}=3)\end{array}$ & $\begin{array}{c}0 \% \\
(\mathrm{n}=0)\end{array}$ & $\begin{array}{l}50 \% \\
(n=3)\end{array}$ \\
\hline $\begin{array}{l}\text { Associate Colleges } \\
\text { (total responses }=20 \text { ) }\end{array}$ & $\begin{array}{l}30 \% \\
(\mathrm{n}=6)\end{array}$ & $\begin{array}{l}10 \% \\
(\mathrm{n}=2)\end{array}$ & $\begin{array}{c}60 \% \\
(\mathrm{n}=12)\end{array}$ \\
\hline $\begin{array}{l}\text { Specialized Institutions } \\
\text { (total responses }=4 \text { ) }\end{array}$ & $\begin{array}{l}25 \% \\
(n=1)\end{array}$ & $\begin{array}{c}0 \% \\
(\mathrm{n}=0)\end{array}$ & $\begin{array}{l}75 \% \\
(n=3)\end{array}$ \\
\hline Total Responses $(n=59)$ & $\begin{array}{c}37 \% \\
(n=22)\end{array}$ & $\begin{array}{l}12 \% \\
(\mathrm{n}=7)\end{array}$ & $\begin{array}{c}51 \% \\
(n=30)\end{array}$ \\
\hline
\end{tabular}

thirteen $(22 \%)$ organizations $(n=60)$. The chain of command during the approval process may also reflect the organizational structure of the institution and the library's place within that hierarchy. Only twelve (18\%) administrators addressed the question about the library's role on an institution-wide travel committee. Five of those (42\%) indicated that the library may participate on such a committee. The lack of response to this question may be more indicative of the lack of that kind of committee in the organization rather than the fact that librarians may not participate. The finding here is more encouraging than the response to a similar question asked of academic librarians in Alabama. Darby and Weatherford reported that while $60 \%$ of the 
Alabama respondents were eligible for travel funding at the institutional level, $71 \%$ of them did not have a library representative on the campus committee that decided travel allocations. ${ }^{32}$ Massman found that librarians in Michigan, Minnesota, and Wisconsin were more likely to receive travel funds than the teaching faculty. ${ }^{33}$ A study of academic library directors in North Carolina showed that $51 \%$ of their librarians had the same access to travel funds as their research faculty. ${ }^{34}$

Non-union academic institutions $(71 \%, 46$ of 65$)$ exceed union members $(29 \%, 19$ of 65$)$ in Florida. Spang and Kane's 1997 study of 201 academic librarians seems to indicate that librarians who are not affiliated with a union may have a slightly better opportunity to procure travel funding than those in unionized positions. ${ }^{35}$ In contrast, the Florida study discovered unionized libraries having a slight advantage over the non-unionized libraries (Table 5) and a much higher level of travel support overall.

Table 5

Comparison of Research Support for Unionized versus Non-unionized Libraries

\begin{tabular}{lcccc}
\hline & $\begin{array}{c}\text { Research } \\
\text { Required }\end{array}$ & $\begin{array}{c}\text { Availability of } \\
\text { Sabbaticals }\end{array}$ & $\begin{array}{c}\text { Availability of } \\
\text { Travel Funds }\end{array}$ & $\begin{array}{c}\text { Availability of } \\
\text { Research Funds }\end{array}$ \\
\hline $\begin{array}{l}\text { Unionized } \\
\text { Libraries }\end{array}$ & $44 \%$ & $89 \%$ & $100 \%$ & $89 \%$ \\
& $(7$ of 16$)$ & $(17$ of 19$)$ & $(18$ of 18$)$ & $(17$ of 19$)$ \\
$\begin{array}{l}\text { Non-unionized } \\
\text { Libraries }\end{array}$ & $20 \%$ & $52 \%$ & $93 \%$ & $44 \%$ \\
$(9$ of 46$)$ & $(23$ of 44$)$ & $(42$ of 45$)$ & $(19$ of 43$)$
\end{tabular}

Table 6 describes eligibility for travel funds. Although $98 \%$ of the full-time librarians may apply for funding, a substantial difference is seen with part-time librarians where only $37 \%$ are allowed to request travel funds. A similar trend is seen with regard to paraprofessionals; $86 \%$ of the permanent paraprofessionals have access to travel funds while only $25 \%$ of the part-time staff have this benefit. It is interesting to note that temporary librarians are eligible for travel funding at more than $10 \%$ of the Florida organizations. The survey also indicated that other 
Florida library employees, such as development officers, students, or other personnel services (OPS) employees may also have this privilege. Although a 1989 study of ARL institutions found similar results for the full-time librarians with $99 \%$ eligible for travel funds, that study reported higher levels of funding for part-time (70\%) and temporary librarians (38\%). Sixty-eight percent of the paraprofessionals in the ARL study were eligible for funding. ${ }^{36}$

Table 6

Eligibility for Travel Funding

\begin{tabular}{lcc}
\hline & $\begin{array}{c}\text { Total } \\
\text { Responses } \\
(\mathbf{n = 6 3 )}\end{array}$ & $\begin{array}{c}\text { Percent of } \\
\text { Responses }\end{array}$ \\
\hline Full-time Librarians & 62 & $98 \%$ \\
Part-time Librarians & 23 & $37 \%$ \\
Temporary Librarians & 7 & $11 \%$ \\
Permanent Paraprofessional Staff & 54 & $86 \%$ \\
Part-time Paraprofessional Staff & 16 & $25 \%$ \\
Temporary Paraprofessional Staff & 2 & $3 \%$ \\
Other & 7 & $11 \%$
\end{tabular}

Tables 7 and 8 present the ranking criteria for travel funding. As expected, those librarians presenting at either national or state conferences received the highest priority for funding. Serving on committees in the state or national professional associations ranked next, averaging $61 \%$ in the "high priority" category. Several administrators remarked that relevance to job duties and value to the organization were important factors considered as well. In this study, librarians with fewer years in rank have a modest advantage in funding decisions over those with seniority status. Blomberg and Chapman found a greater disparity in their 1989 survey of ARL Libraries with $27 \%$ of new or recently hired librarians receiving special consideration for travel funding compared to only $4 \%$ of the more experienced librarians. Library administrators in Florida receive the highest funding priority at $40 \%$, similar to the $33 \%$ level of funding for ARL administrators in the 1989 study. ${ }^{37}$ 
Table 7

Travel Funding Considerations Based on Reason for Attendance

\begin{tabular}{|c|c|c|c|c|}
\hline & $\begin{array}{c}\text { High } \\
\text { Priority }\end{array}$ & Considered & $\begin{array}{c}\text { Low } \\
\text { Priority }\end{array}$ & $\begin{array}{c}\text { Not } \\
\text { Considered }\end{array}$ \\
\hline $\begin{array}{l}\text { Librarians presenting at a national } \\
\text { library workshop or conference } \\
\text { (total responses }=62 \text { ) }\end{array}$ & $\begin{array}{c}89 \% \\
(\mathrm{n}=55)\end{array}$ & $\begin{array}{c}8 \% \\
(n=5)\end{array}$ & $\begin{array}{c}0 \% \\
(\mathrm{n}=0)\end{array}$ & $\begin{array}{c}3 \% \\
(\mathrm{n}=2)\end{array}$ \\
\hline $\begin{array}{l}\text { Librarians presenting at a state or } \\
\text { regional library workshop or conference } \\
\text { (total responses }=62 \text { ) }\end{array}$ & $\begin{array}{c}81 \% \\
(\mathrm{n}=50)\end{array}$ & $\begin{array}{c}16 \% \\
(n=10)\end{array}$ & $\begin{array}{c}0 \% \\
(\mathrm{n}=0)\end{array}$ & $\begin{array}{c}3 \% \\
(\mathrm{n}=2)\end{array}$ \\
\hline $\begin{array}{l}\text { Librarians presenting at a non-library } \\
\text { association conference or workshop } \\
\text { (total responses }=63 \text { ) }\end{array}$ & $\begin{array}{c}48 \% \\
(n=30)\end{array}$ & $\begin{array}{c}37 \% \\
(n=23)\end{array}$ & $\begin{array}{c}6 \% \\
(\mathrm{n}=4)\end{array}$ & $\begin{array}{c}10 \% \\
(\mathrm{n}=6)\end{array}$ \\
\hline $\begin{array}{l}\text { Committee members attending national } \\
\text { library association committee meetings } \\
\text { (total responses }=62 \text { ) }\end{array}$ & $\begin{array}{c}61 \% \\
(\mathrm{n}=38)\end{array}$ & $\begin{array}{c}24 \% \\
(\mathrm{n}=15)\end{array}$ & $\begin{array}{c}8 \% \\
(n=5)\end{array}$ & $\begin{array}{c}6 \% \\
(n=4)\end{array}$ \\
\hline $\begin{array}{l}\text { Committee members attending state or } \\
\text { regional library association committee } \\
\text { meetings (total responses }=62 \text { ) }\end{array}$ & $\begin{array}{c}60 \% \\
(n=37)\end{array}$ & $\begin{array}{c}34 \% \\
(\mathrm{n}=21)\end{array}$ & $\begin{array}{c}2 \% \\
(n=1)\end{array}$ & $\begin{array}{c}5 \% \\
(n=3)\end{array}$ \\
\hline $\begin{array}{l}\text { Committee members attending non- } \\
\text { library association committee meeting } \\
\text { (total responses }=62 \text { ) }\end{array}$ & $\begin{array}{c}27 \% \\
(\mathrm{n}=17)\end{array}$ & $\begin{array}{c}35 \% \\
(n=22)\end{array}$ & $\begin{array}{c}26 \% \\
(n=16)\end{array}$ & $\begin{array}{c}11 \% \\
(\mathrm{n}=7)\end{array}$ \\
\hline $\begin{array}{l}\text { Members of an association attending a } \\
\text { national library conference or workshop } \\
\text { (total responses }=63 \text { ) }\end{array}$ & $\begin{array}{c}44 \% \\
(n=28)\end{array}$ & $\begin{array}{c}48 \% \\
(n=30)\end{array}$ & $\begin{array}{c}5 \% \\
(n=3)\end{array}$ & $\begin{array}{c}3 \% \\
(\mathrm{n}=2)\end{array}$ \\
\hline $\begin{array}{l}\text { Members of an association attending a } \\
\text { state or regional library conference or } \\
\text { workshop (total responses }=63 \text { ) }\end{array}$ & $\begin{array}{c}48 \% \\
(n=30)\end{array}$ & $\begin{array}{c}48 \% \\
(n=30)\end{array}$ & $\begin{array}{c}2 \% \\
(n=1)\end{array}$ & $\begin{array}{c}3 \% \\
(\mathrm{n}=2)\end{array}$ \\
\hline $\begin{array}{l}\text { Non-members of an association } \\
\text { attending a national library conference } \\
\text { or workshop } \\
\text { (total responses }=63 \text { ) }\end{array}$ & $\begin{array}{c}8 \% \\
(\mathrm{n}=5)\end{array}$ & $\begin{array}{c}38 \% \\
(\mathrm{n}=24)\end{array}$ & $\begin{array}{c}40 \% \\
(n=25)\end{array}$ & $\begin{array}{l}14 \% \\
(n=9)\end{array}$ \\
\hline $\begin{array}{l}\text { Non-members of an association } \\
\text { attending a state or regional library } \\
\text { conference or workshop (total responses } \\
=63 \text { ) }\end{array}$ & $\begin{array}{c}10 \% \\
(\mathrm{n}=6)\end{array}$ & $\begin{array}{c}44 \% \\
(n=28)\end{array}$ & $\begin{array}{c}32 \% \\
(\mathrm{n}=20)\end{array}$ & $\begin{array}{c}14 \% \\
(\mathrm{n}=9)\end{array}$ \\
\hline $\begin{array}{l}\text { Attendance at a non-library association } \\
\text { conference or workshop } \\
\text { (total responses }=62 \text { ) }\end{array}$ & $\begin{array}{c}6 \% \\
(n=4)\end{array}$ & $\begin{array}{c}42 \% \\
(n=26)\end{array}$ & $\begin{array}{c}40 \% \\
(n=25)\end{array}$ & $\begin{array}{l}11 \% \\
(n=7)\end{array}$ \\
\hline
\end{tabular}


Table 8

Travel Funding Considerations Based on Rank or Service

\begin{tabular}{|c|c|c|c|c|}
\hline & High Priority & Considered & Low Priority & $\begin{array}{c}\text { Not } \\
\text { Considered } \\
\end{array}$ \\
\hline $\begin{array}{l}\text { Length of service at the } \\
\text { library (total responses=58) }\end{array}$ & $\begin{array}{c}7 \% \\
(n=4)\end{array}$ & $\begin{array}{l}29 \% \\
(\mathrm{n}=17)\end{array}$ & $\begin{array}{l}24 \% \\
(\mathrm{n}=14)\end{array}$ & $\begin{array}{c}40 \% \\
(n=23)\end{array}$ \\
\hline $\begin{array}{l}\text { First-come, first-serve basis } \\
\text { (total responses }=59 \text { ) }\end{array}$ & $\begin{array}{c}20 \% \\
(\mathrm{n}=12)\end{array}$ & $\begin{array}{l}27 \% \\
(\mathrm{n}=16)\end{array}$ & $\begin{array}{c}22 \% \\
(n=13)\end{array}$ & $\begin{array}{l}31 \% \\
(\mathrm{n}=18)\end{array}$ \\
\hline $\begin{array}{l}\text { Senior librarians (tenured } \\
\text { or at associate or full } \\
\text { professor level) (total } \\
\text { responses }=59 \text { ) }\end{array}$ & $\begin{array}{c}17 \% \\
(\mathrm{n}=10)\end{array}$ & $\begin{array}{c}41 \% \\
(n=24)\end{array}$ & $\begin{array}{l}14 \% \\
(\mathrm{n}=8)\end{array}$ & $\begin{array}{c}29 \% \\
(\mathrm{n}=17)\end{array}$ \\
\hline $\begin{array}{l}\text { Newer librarians } \\
\text { (untenured or still eligible } \\
\text { for promotion) } \\
\text { (total responses }=59 \text { ) }\end{array}$ & $\begin{array}{c}22 \% \\
(\mathrm{n}=13)\end{array}$ & $\begin{array}{c}51 \% \\
(\mathrm{n}=30)\end{array}$ & $\begin{array}{l}7 \% \\
(n=4)\end{array}$ & $\begin{array}{c}20 \% \\
(n=12)\end{array}$ \\
\hline $\begin{array}{l}\text { Library Administrators } \\
\text { (Deans, Directors, or } \\
\text { Department Heads) } \\
\text { (total responses }=60 \text { ) }\end{array}$ & $\begin{array}{c}40 \% \\
(n=24)\end{array}$ & $\begin{array}{c}38 \% \\
(\mathrm{n}=23)\end{array}$ & $\begin{array}{l}2 \% \\
(\mathrm{n}=1)\end{array}$ & $\begin{array}{c}20 \% \\
(\mathrm{n}=12)\end{array}$ \\
\hline
\end{tabular}

The survey identified several sources of travel funds; the most prevalent being a direct line in the library budget. Financial support was also available from library discretionary funds and campus-wide travel sources. Forty-one percent of the libraries in this study receive funding from more than one source. Table 9 illustrates the variety of funding resources available. Cramer's ARL survey found that most $(70 \%)$ of his respondents funded travel from the library's own budget. $^{38}$

Table 9

Sources of Travel Funds

\begin{tabular}{lcc}
\hline & $\begin{array}{c}\text { Total Responses } \\
(\mathbf{n = 6 3 )}\end{array}$ & $\begin{array}{c}\text { Percent of } \\
\text { Responses }\end{array}$ \\
\hline Direct line item in the library budget & 44 & $70 \%$ \\
Discretionary funds from the library budget & 17 & $27 \%$ \\
Campus travel funds & 21 & $33 \%$ \\
Endowments & 5 & $8 \%$ \\
Other* & 8 & $13 \%$ \\
Multiple sources available & 26 & $41 \%$
\end{tabular}

*other sources include grants and college professional development funds 
Few of the Florida academic libraries claimed to have written travel policies (15 of 58, $26 \%$ ), yet $90 \%$ of the ARL libraries surveyed in a 1989 study had written policies. ${ }^{39}$ Forty-six percent (27 of 59) of the Florida librarians are required to give a report after travel has been completed. Additionally, respondents commented that although not required, many libraries informally share information gleaned from their travel with others at staff meetings, brown bags, and other venues. International travel funding requests are allowed at 44\% (26 of 59) of the organizations. Several respondents provided additional insights. International travel appears to be rare and permission may require additional authority. Others explain that travel funding may be available in conjunction with other projects and/or organizations.

Reimbursement of specific types of travel expenses was also explored. Although more than $80 \%$ of the administrators try to reimburse the full cost of most expenses, several commented that it depended on the details of each trip. In the 2003 Florida study, full travel support was reported by $54 \%$ of the total librarians. ${ }^{40}$ A 1982 study of southeastern academic libraries reported full travel funding at $31 \%$ of the institutions. ${ }^{41}$ Although there is a desire to cover the full cost, the reality is that the funds often don't stretch that far. For example, conference registrations vary considerably as do hotel rates and air fares. The majority of administrators reimburse meals on a per diem schedule. A small number (17\%, 10 of 59) reported distributing specific allocations to staff to use as needed. The allocation amounts ranged from $\$ 350$ up to $\$ 3000$ per year. Table 10 provides a more detailed analysis of reimbursement costs.

\section{Research time}

Although research is not required by $70 \%$ of the organizations, a breakdown by Carnegie classification indicates that $65 \%$ of the doctoral institutions expect research yet only $44 \%$ actually include a research component in a job assignment. Table 11 provides a breakdown of 
research requirements by Carnegie Class. Only 16\% (10 of 64) of the total institutions officially include research in their job assignments. There do not appear to be substantial differences between the assignment of time allotted to librarians when analyzed according to rank or area of specialization (Table 12).

Table 10

Breakdown of Travel Reimbursement Costs

\begin{tabular}{lcc}
\hline & Full Cost & $\begin{array}{c}\text { Partial Cost or Per } \\
\text { Diem }\end{array}$ \\
\hline $\begin{array}{l}\text { Hotel } \\
\text { total responses=54) }\end{array}$ & $\begin{array}{c}87 \% \\
(\mathrm{n}=47)\end{array}$ & $\begin{array}{c}13 \% \\
(\mathrm{n}=7)\end{array}$ \\
$\begin{array}{l}\text { Air Transportation (total } \\
\text { responses =54) }\end{array}$ & $\begin{array}{c}87 \% \\
(\mathrm{n}=47)\end{array}$ & $\begin{array}{c}13 \% \\
(\mathrm{n}=7)\end{array}$ \\
$\begin{array}{l}\text { Rental Car } \\
\text { total responses =50) }\end{array}$ & $82 \%$ & $18 \%$ \\
$\begin{array}{l}\text { Mileage } \\
\text { (total responses =53) }\end{array}$ & $(\mathrm{n}=41)$ & $(\mathrm{n}=9)$ \\
$\begin{array}{l}\text { Conference Registration } \\
\text { (total responses =54) }\end{array}$ & $\begin{array}{c}79 \% \\
\mathrm{n}=42)\end{array}$ & $\begin{array}{c}21 \% \\
(\mathrm{n}=11)\end{array}$ \\
$\begin{array}{l}\text { Meals } \\
\text { (total responses =51) }\end{array}$ & $89 \%$ & $11 \%$ \\
& $(\mathrm{n}=48)$ & $(\mathrm{n}=6)$ \\
& $41 \%$ & $59 \%$ \\
$(\mathrm{n}=30)$
\end{tabular}

In this study, release time was defined as a set number of hours of release from other professional duties, desk time, and meetings to work on research projects aimed at eventual publication. Surprisingly, regularly assigned formal release time from normal work hours is not prevalent; only $12 \%$ of all the organizations reported this as an available option (Table 13). Of those for whom formal release time is granted, the numbers of hours available ranged from two to five hours a week. Several comments indicate that, for librarians that are allowed to do research during work hours; time management is discretionary. Although few Florida librarians receive regularly scheduled release time, the situation may be better than in Tennessee where Rogers' study noted that $10 \%$ of the respondents actually feared reprimands if they worked on 
research projects during work time. ${ }^{42}$ The current Florida situation for all academic institutions varies only slightly from the data collected during Rayman and Goudy's 1980 survey of ARL library directors. They found that $10 \%$ of the respondents were given specific release time and an additional $41 \%$ could apply for release time to work on publications. ${ }^{43}$ However, when comparing the ARL results with only the doctoral/research libraries in Florida, a greater number of Florida librarians (23\%) were eligible for specific release time. In addition, the majority of the Florida research librarians (87\%) could apply for informal or irregular release time. Irregular release time is possible at $48 \%$ of all of the responding libraries.

Table 11

Research Requirements by Carnegie Class

\begin{tabular}{lc|c}
\hline & Research Required & $\begin{array}{c}\text { Research Included in } \\
\text { Official Job Assignment }\end{array}$ \\
\hline $\begin{array}{l}\text { Doctoral/Research: } \\
\text { Extensive and } \\
\text { Intensive }\end{array}$ & $65 \%$ & $44 \%$ \\
$\begin{array}{l}\text { Master's Colleges } \\
\text { and Universities I }\end{array}$ & $(11$ of 17$)$ & $(7$ of 16$)$ \\
and II & $36 \%$ & $21 \%$ \\
Baccalaureate & $(5$ of 14$)$ & $(3$ of 14$)$ \\
Colleges: General & & $0 \%$ \\
and Liberal Arts & $14 \%$ & $(0$ of 7$)$ \\
Associate Colleges & $(1$ of 7$)$ & $0 \%$ \\
& $0 \%$ & $(0$ of 23$)$ \\
Specialized & $(0$ of 21$)$ & $0 \%$ \\
Institutions & $0 \%$ & $(0$ of 4$)$ \\
& $(0$ of 4$)$ & $16 \%$ \\
Total Responses & $30 \%$ & $(10$ of 64$)$ \\
& $(19$ of 63$)$ &
\end{tabular}

Overall, flex time appears to be only slightly more available than regular release time with $26 \%$ of the libraries offering this benefit. However, in this instance, the doctoral institutions did fare better with $67 \%$ reporting that flex time is an option at their organizations. Although the 
median number of hours librarians were required to be present in the library was 36 hours, one library reported as few as five hours and several reported that librarians needed to be present for forty hours per week.

Table 12

Approximate Research Time Assignments by Rank and Specialization

\begin{tabular}{|c|c|c|c|c|}
\hline & $1-5 \%$ & $5-10 \%$ & $10-20 \%$ & $\begin{array}{c}\text { More than } \\
20 \% \\
\end{array}$ \\
\hline $\begin{array}{l}\text { Administrators } \\
\text { (total responses=9) }\end{array}$ & $\begin{array}{l}56 \% \\
(\mathrm{n}=5)\end{array}$ & $\begin{array}{l}22 \% \\
(n=2)\end{array}$ & $\begin{array}{l}22 \% \\
(n=2)\end{array}$ & $\begin{array}{c}0 \% \\
(\mathrm{n}=0)\end{array}$ \\
\hline $\begin{array}{l}\text { Senior Librarians (Associate or } \\
\text { Full Professor) } \\
(\text { total responses }=12 \text { ) }\end{array}$ & $\begin{array}{l}25 \% \\
(\mathrm{n}=3)\end{array}$ & $\begin{array}{l}42 \% \\
(n=5)\end{array}$ & $\begin{array}{l}25 \% \\
(\mathrm{n}=3)\end{array}$ & $\begin{array}{c}8 \% \\
(\mathrm{n}=1)\end{array}$ \\
\hline $\begin{array}{l}\text { Newer Librarians (Instructor or } \\
\text { Assistant Professor) } \\
\text { (total responses }=12 \text { ) }\end{array}$ & $\begin{array}{l}25 \% \\
(\mathrm{n}=3)\end{array}$ & $\begin{array}{l}42 \% \\
(n=5)\end{array}$ & $\begin{array}{l}25 \% \\
(n=3)\end{array}$ & $\begin{array}{c}8 \% \\
(\mathrm{n}=1)\end{array}$ \\
\hline $\begin{array}{l}\text { Other Rank } \\
(\text { total responses }=2)\end{array}$ & $\begin{array}{c}0 \% \\
(\mathrm{n}=0)\end{array}$ & $\begin{array}{l}50 \% \\
(n=1)\end{array}$ & $\begin{array}{l}50 \% \\
(n=1)\end{array}$ & $\begin{array}{c}0 \% \\
(\mathrm{n}=0)\end{array}$ \\
\hline $\begin{array}{l}\text { Technical Service } \\
(\text { total responses }=10)\end{array}$ & $\begin{array}{l}30 \% \\
(\mathrm{n}=3)\end{array}$ & $\begin{array}{l}40 \% \\
(n=4)\end{array}$ & $\begin{array}{l}30 \% \\
(n=3)\end{array}$ & $\begin{array}{c}0 \% \\
(\mathrm{n}=0)\end{array}$ \\
\hline $\begin{array}{l}\text { Public Service } \\
(\text { total responses }=11 \text { ) }\end{array}$ & $\begin{array}{l}27 \% \\
(\mathrm{n}=3)\end{array}$ & $\begin{array}{l}36 \% \\
(n=4)\end{array}$ & $\begin{array}{l}27 \% \\
(\mathrm{n}=3)\end{array}$ & $\begin{array}{l}10 \% \\
(\mathrm{n}=1)\end{array}$ \\
\hline $\begin{array}{l}\text { Archivist } \\
(\text { total responses =6) }\end{array}$ & $\begin{array}{l}33 \% \\
(\mathrm{n}=2)\end{array}$ & $\begin{array}{l}17 \% \\
(\mathrm{n}=1)\end{array}$ & $\begin{array}{l}50 \% \\
(n=3)\end{array}$ & $\begin{array}{c}0 \% \\
(\mathrm{n}=0)\end{array}$ \\
\hline $\begin{array}{l}\text { Other Specialization } \\
\text { (total responses }=4 \text { ) }\end{array}$ & $\begin{array}{c}0 \% \\
(\mathrm{n}=0)\end{array}$ & $\begin{array}{l}25 \% \\
(\mathrm{n}=1)\end{array}$ & $\begin{array}{l}50 \% \\
(\mathrm{n}=2)\end{array}$ & $\begin{array}{l}25 \% \\
(\mathrm{n}=1)\end{array}$ \\
\hline
\end{tabular}

For the purposes of this study a sabbatical was defined as a lengthy (one semester to one year) professional development leave at full or half pay to enhance a faculty member's career and to increase their value to the institution through opportunities for research-related travel, study, writing, or other experiences of professional value. Sixty-three percent of the administrators indicated that their librarians were eligible for sabbaticals (Table 13). While 82\% 
of the associate colleges allow librarians to participate, only $59 \%$ of the doctoral / research institutions allow librarians into the sabbatical program. An early telephone survey of Florida academic librarians, at institutions offering bachelor's degrees or above, indicates that a larger number of librarians may have been eligible for sabbaticals than this study shows. ${ }^{44}$

Table 13

Time Allowed for Research

\begin{tabular}{|c|c|c|c|c|}
\hline & $\begin{array}{l}\text { Eligible for } \\
\text { Regular } \\
\text { Release Time }\end{array}$ & $\begin{array}{c}\text { Flexible } \\
\text { Schedule } \\
\text { Permitted }\end{array}$ & $\begin{array}{c}\text { Informal or } \\
\text { Irregular } \\
\text { Release Time } \\
\text { Available } \\
\end{array}$ & $\begin{array}{l}\text { Eligible for } \\
\text { Sabbaticals }\end{array}$ \\
\hline $\begin{array}{l}\text { Doctoral/Research: } \\
\text { Extensive and } \\
\text { Intensive }\end{array}$ & $\begin{array}{c}23 \% \\
(3 \text { of } 13)\end{array}$ & $\begin{array}{c}67 \% \\
\text { (10 of } 15)\end{array}$ & $\begin{array}{c}87 \% \\
\text { (13 of } 15)\end{array}$ & $\begin{array}{c}59 \% \\
(10 \text { of } 17)\end{array}$ \\
\hline $\begin{array}{l}\text { Master's Colleges } \\
\text { and Universities I } \\
\text { and II }\end{array}$ & $\begin{array}{c}21 \% \\
\text { (3 of } 14)\end{array}$ & $\begin{array}{c}14 \% \\
(2 \text { of } 14)\end{array}$ & $\begin{array}{c}43 \% \\
(6 \text { of } 14)\end{array}$ & $\begin{array}{c}64 \% \\
\text { (9 of } 14)\end{array}$ \\
\hline $\begin{array}{l}\text { Baccalaureate } \\
\text { Colleges: General } \\
\text { and Liberal Arts }\end{array}$ & $\begin{array}{c}0 \% \\
(0 \text { of } 7)\end{array}$ & $\begin{array}{c}0 \% \\
(0 \text { of } 7)\end{array}$ & $\begin{array}{c}43 \% \\
\text { (3 of } 7)\end{array}$ & $\begin{array}{c}43 \% \\
\text { (3 of } 7)\end{array}$ \\
\hline Associate Colleges & $\begin{array}{c}5 \% \\
(1 \text { of } 22)\end{array}$ & $\begin{array}{c}12 \% \\
(2 \text { of } 17)\end{array}$ & $\begin{array}{c}25 \% \\
(4 \text { of } 16)\end{array}$ & $\begin{array}{c}82 \% \\
(18 \text { of } 22)\end{array}$ \\
\hline $\begin{array}{l}\text { Specialized } \\
\text { Institutions }\end{array}$ & $\begin{array}{c}0 \% \\
(0 \text { of } 4)\end{array}$ & $\begin{array}{c}25 \% \\
(1 \text { of } 4)\end{array}$ & $\begin{array}{c}25 \% \\
(1 \text { of } 4)\end{array}$ & $\begin{array}{c}0 \% \\
(0 \text { of } 3)\end{array}$ \\
\hline Total Institutions & $\begin{array}{c}12 \% \\
(7 \text { of } 60)\end{array}$ & $\begin{array}{c}26 \% \\
(15 \text { of } 57)\end{array}$ & $\begin{array}{c}48 \% \\
(27 \text { of } 56)\end{array}$ & $\begin{array}{c}63 \% \\
(40 \text { of } 63)\end{array}$ \\
\hline
\end{tabular}

The current Florida opportunities are slightly more promising than those reported by Boughter back in 1958. In her study of academic institutions in West Virginia and surrounding areas, only $47 \%$ of the respondents indicated the eligibility for sabbatical leaves for librarians even though $56 \%$ of them were at institutions that allowed sabbaticals for their regular teaching faculty. ${ }^{45}$ Fifty-nine percent of the respondents to a 1997 survey of small- and medium-sized 
libraries had access to sabbatical opportunities of the same length as those of the teaching faculty at their institutions. ${ }^{46}$ Gaskell and Morrill had similar findings in their 2000 survey of college librarians where $56 \%$ were at institutions that offered sabbaticals to librarians. Most sabbaticals in their study were for six months. ${ }^{47}$ In contrast, only $10 \%$ of the librarians surveyed in the 1994 Tennessee study were eligible for one year sabbaticals and only $9 \%$ of the respondents were allowed one semester faculty development leaves. ${ }^{48}$ A large study of California academic librarians found that some librarians joined unions because of the role that the union had played in providing them with better access to sabbaticals and to ten-month contracts. ${ }^{49}$ Not surprisingly, Spang and Kane found that unionized librarians might have a slight advantage with regard to access to sabbaticals and professional development leaves. ${ }^{50}$ This study implies a much larger advantage for unionized Florida librarians with $89 \%$ of the unionized librarians eligible for sabbaticals compared to $52 \%$ of the unaffiliated librarians (Table 5).

Time for research may not have to be as constraining as it seems at first glance. Robert Sewell provides a number of useful suggestions on ways that research time might be incorporated into the librarian's work load while still maintaining good service. He provides examples of library faculty who, with the approval of their supervisor, are setting their own work schedules rather than strictly adhering to the standard work week. ${ }^{51}$ Librarians at Western Illinois University have also experimented with providing greater scheduling flexibility that is more in line with their teaching faculty colleagues. ${ }^{52}$

\section{Research funding}

Thirty-six organizations $(56 \%, \mathrm{n}=64)$ permit libraries to apply for internal funding of some type. Table 14 illustrates the variety of funding available. The majority of the research support comes from either institutional grants (66\%) and/or discretionary funds (24\%) from the library. No Florida library administrator indicated that research funds were a direct line item in 
the library budget. The overall Florida figure compares favorably with the 1980 survey of ARL libraries where $51 \%$ were able to apply for institutional funding for research and only $26 \%$ did not have any options for research funding. ${ }^{53}$ A greater number of the Florida librarians (44\%, 28 of 64) however are without any funding options. Doctoral /research (71\%, 12 of 17) and master's college librarians $(64 \%, 9$ of 14$)$ in Florida have more access to funds than their colleagues. Surprisingly, two of the doctoral institutions reported that, while research is required, the librarians are not eligible for internal funding. The current overall figure from Florida appears lower than those responding to DePew's early study of Florida academic librarians; ${ }^{54}$ however, funding availability among unionized Florida libraries now is much higher (89\%) than non-unionized (Table 5). A 1984 non-ARL libraries survey reported that $65 \%$ could apply for university-level funding although, interestingly, only $19 \%$ reported that internal library funds were available. ${ }^{55}$ A 1991 study of academic librarians in Oklahoma reported that $65.9 \%$ of the respondents to their survey had some kind of financial assistance available from their institution. ${ }^{56}$ Leysen and Black found that institutional funding was available for $88 \%$ of the librarians at Carnegie Research I and II institutions where the librarians had faculty status with publishing as a requirement for tenure. ${ }^{57}$

Table 14 Sources of Funding for Research

\begin{tabular}{lcc}
\hline & $\begin{array}{c}\text { Total Responses } \\
(\mathrm{n}=41)\end{array}$ & $\begin{array}{c}\text { Percent of } \\
\text { Responses }\end{array}$ \\
\hline $\begin{array}{l}\text { Direct Line in the Library Budget } \\
\text { Discretional Funds from the Library } \\
\text { Budget }\end{array}$ & 0 & $0 \%$ \\
Institutional Internal Seed Grants & 10 & $24 \%$ \\
Other & 27 & $66 \%$ \\
Multiple Sources Available & 4 & $10 \%$ \\
\end{tabular}


Table 15 presents the types of support available to Florida academic librarians for research. Not surprisingly, support for equipment, software, photocopying, and mailing appears to be the most prevalent. Funds for any type of compensation (small gifts for survey or focus group volunteers) are available for some but are not nearly as common.

Table 15

Types of Research Funding Support Available

\begin{tabular}{lc}
\hline & $\begin{array}{c}\text { Funding May be Available } \\
\text { on Request }\end{array}$ \\
\hline $\begin{array}{l}\text { Equipment } \\
\text { (total responses=41) }\end{array}$ & $\begin{array}{c}85 \% \\
(\mathrm{n}=35)\end{array}$ \\
$\begin{array}{l}\text { Software } \\
\text { (total responses =39) }\end{array}$ & $79 \%$ \\
& $(\mathrm{n}=31)$ \\
$\begin{array}{l}\text { Clerical support for typing, grant administration, } \\
\text { etc. (total responses =40) }\end{array}$ & $\begin{array}{c}43 \% \\
(\mathrm{n}=17)\end{array}$ \\
$\begin{array}{l}\text { Photocopying supplies } \\
\text { (total responses =40) }\end{array}$ & $\begin{array}{c}85 \% \\
(\mathrm{n}=34)\end{array}$ \\
$\begin{array}{l}\text { Mailing supplies/postage } \\
\text { (total responses =39) }\end{array}$ & $72 \%$ \\
$\begin{array}{l}\text { Student or graduate assistant help } \\
\text { (total responses =38) }\end{array}$ & $(\mathrm{n}=28)$ \\
$\begin{array}{l}\text { Money for buying small gifts to compensate } \\
\text { volunteers that respond to focus groups, surveys, etc. } \\
\text { (total responses =38) }\end{array}$ & $50 \%$ \\
$(\mathrm{n}=19)$ \\
\end{tabular}

Research guidance

The availability of mentoring or other types of research guidance was also investigated by the survey (Table 16). Informal mentoring was the most often cited (53\%) form of support. Formal mentoring is unusual in Florida academic libraries. Even among the doctoral research institutions, only $18 \%$ in this category have a formal mentoring program. Informal mentoring, 
however, takes place much more often in doctoral libraries (82\%) than it does in masters, baccalaureate, or associate institutions. Associate and baccalaureate college libraries report far less guidance of any kind than the other types of Carnegie institutions.

Cosgriff's 1986 survey of ARL libraries reported that $87.2 \%$ of the respondents did not have a research committee to support librarians in their research efforts. ${ }^{58}$ This study found a similar situation where only $10 \%$ of the Florida institutions have established a research committee for their librarians. However, librarians at Auburn University provide strong evidence of the value of their Library Research Advisory Committee. The Auburn committee provides reviews and editorial guidance for research proposals. They also sponsor workshops, purchase computer equipment and software to help with research activities, and communicate information about research opportunities that may be relevant to their librarians. Since the committee was established in 1987, the Auburn librarians' scholarly productivity has increased by nearly $90 \%{ }^{59}$

\section{Membership in professional organizations}

Florida library administrators were asked to rank the importance of memberships in professional associations with regard to tenure or promotion advances (Table 17). Overall, very few institutions require membership in a national organization although $57 \%$ recommend affiliation (required, strongly recommended, or considered) for tenure and promotion purposes. Membership dues may be a financial constraint for individual librarians. Although fifteen libraries reported that they do pay the full amount of fees for membership in a library association, responsibility for payment falls to the individual librarian in the majority (74\%) (Table 18). This appears to be similar to other academic libraries as indicated by a 2002 survey of academic librarians in Alabama where $77 \%$ were not reimbursed for membership dues in professional organizations. ${ }^{60}$ 
Table 16

Types of Research Guidance Available

\begin{tabular}{|c|c|c|c|c|}
\hline & $\begin{array}{c}\text { Formal } \\
\text { Mentoring }\end{array}$ & $\begin{array}{c}\text { Informal } \\
\text { Mentoring }\end{array}$ & $\begin{array}{l}\text { Library Research } \\
\text { Committee }\end{array}$ & $\begin{array}{c}\text { No Specific Guidance } \\
\text { Provided }\end{array}$ \\
\hline $\begin{array}{l}\text { Doctoral/Research: } \\
\text { Extensive and } \\
\text { Intensive }\end{array}$ & $\begin{array}{c}18 \% \\
\text { (3 of } 17)\end{array}$ & $\begin{array}{c}82 \% \\
(14 \text { of } 17)\end{array}$ & $\begin{array}{c}24 \% \\
(4 \text { of } 17)\end{array}$ & $\begin{array}{c}18 \% \\
\text { (3 of } 17)\end{array}$ \\
\hline $\begin{array}{l}\text { Master's Colleges } \\
\text { and Universities I } \\
\text { and II }\end{array}$ & $\begin{array}{c}14 \% \\
(2 \text { of } 14)\end{array}$ & $\begin{array}{c}57 \% \\
(8 \text { of } 14)\end{array}$ & $\begin{array}{c}0 \% \\
(0 \text { of } 14)\end{array}$ & $\begin{array}{c}43 \% \\
(6 \text { of } 14)\end{array}$ \\
\hline $\begin{array}{l}\text { Baccalaureate } \\
\text { Colleges: General } \\
\text { and Liberal Arts }\end{array}$ & $\begin{array}{c}0 \% \\
(0 \text { of } 6)\end{array}$ & $\begin{array}{c}33 \% \\
(2 \text { of } 6)\end{array}$ & $\begin{array}{c}17 \% \\
(1 \text { of } 6)\end{array}$ & $\begin{array}{c}83 \% \\
(5 \text { of } 6)\end{array}$ \\
\hline Associate Colleges & $\begin{array}{c}0 \% \\
(0 \text { of } 17)\end{array}$ & $\begin{array}{c}29 \% \\
(5 \text { of } 17)\end{array}$ & $\begin{array}{c}6 \% \\
(1 \text { of } 17)\end{array}$ & $\begin{array}{c}72 \% \\
\text { (13 of } 18)\end{array}$ \\
\hline $\begin{array}{l}\text { Specialized } \\
\text { Institutions }\end{array}$ & $\begin{array}{c}0 \% \\
(0 \text { of } 4)\end{array}$ & $\begin{array}{c}50 \% \\
(2 \text { of } 4)\end{array}$ & $\begin{array}{c}0 \% \\
(0 \text { of } 4)\end{array}$ & $\begin{array}{l}100 \% \\
(3 \text { of } 3)\end{array}$ \\
\hline Total Institutions & $\begin{array}{c}9 \% \\
(5 \text { of } 58)\end{array}$ & $\begin{array}{c}53 \% \\
(31 \text { of } 58)\end{array}$ & $\begin{array}{c}10 \% \\
(6 \text { of } 58)\end{array}$ & $\begin{array}{c}52 \% \\
\text { (30 of } 58)\end{array}$ \\
\hline
\end{tabular}


This is quite a contrast to the situation for public librarians in Florida. An August 2005 survey learned that $79 \%$ of public library directors in Florida receive statewide membership dues from their institution. In addition, the survey found that $43 \%$ of public librarians and 19\% of public library staff in Florida have their state membership fees covered by their institutions. ${ }^{61}$

\section{Table 17}

Consideration of Membership in Professional Organizations in Relation to Promotion and/or Tenure Decisions

\section{\begin{tabular}{l}
\hline \\
\hline Membership in a
\end{tabular}}

Association

(total responses $=61$ )

\begin{tabular}{ccccc} 
Required & $\begin{array}{c}\text { Strongly } \\
\text { Considered }\end{array}$ & Considered & $\begin{array}{c}\text { Not } \\
\text { Required }\end{array}$ & $\begin{array}{c}\text { Not } \\
\text { Applicable }\end{array}$ \\
\hline
\end{tabular}

Membership in the

State Library

Association

$0 \%$

$(\mathrm{n}=0)$

$18 \%$

$(\mathrm{n}=11)$

$27 \%$

$(\mathrm{n}=16)$

$16 \%$

$(\mathrm{n}=10)$

$41 \%$

$(\mathrm{n}=25)$

$2 \%$

$(\mathrm{n}=1)$

(total responses=60)

\section{Membership in a}

Regional or Local

Library

Organization

$\begin{array}{ccccc}0 \% & 15 \% & 33 \% & 51 \% & 2 \% \\ (\mathrm{n}=0) & (\mathrm{n}=9) & (\mathrm{n}=20) & (\mathrm{n}=31) & (\mathrm{n}=1)\end{array}$

(total responses=61)

Membership in a

Non-library

Professional

Organization

$0 \% \quad 7 \%$

$(\mathrm{n}=0)$

$(\mathrm{n}=4)$

$39 \%$

$(\mathrm{n}=24)$

$52 \%$

$(\mathrm{n}=32)$

$2 \%$

$(\mathrm{n}=1)$

(total responses $=61$ ) 
Table 18

Payment of Library Association Membership Fees

$(n=62)$

\section{Responses Percent of Responses}

Institution Pays for Full

Library Association

Membership

Institution Pays for Partial

Library Association

Membership

Individual is Personally

Responsible for All

Library Association

Membership Fees
15

$24 \%$

1

$2 \%$

46
$74 \%$

\section{Conclusions}

Overall, Florida library administrations appear to support travel for research and professional development in a manner similar to their regional colleagues. However, while full-time professionals are supported at a level on a par with ARL institutions, parttime librarians and paraprofessional staff receive considerably less support. This study also indicates that incorporating a formal research requirement into a job assignment does not necessarily ensure support for that assignment.

Although aware that the day-to-day activities must be covered, academic librarians who are required to do research, publish, and/or pursue other scholarly activities find that adequate time for these activities remains a critical issue. As a participant in an earlier study noted, "librarians can't publish effectively in a 'time clock' environment." ${ }^{, 62}$ Creative solutions to work schedule problems such as those described in studies by Goudy and Sewell need to become the norm rather than the exception. ${ }^{63}$ 
Although release time for Florida librarians compares well with data reported from the ARL and non-ARL library surveys, adopting more flexibility in the scheduling of routine library duties may help reduce the level of stress associated with research. Likewise, research funding is comparable to other studies.

Formal mentoring is minimal. Although this study does not explore reasons behind this finding, formal mentoring may place difficult time constraints on participants and thus make the program hard to maintain. On the other hand, informal mentoring, as one might expect in a collegial academic environment, is quite common.

Support for research is critical if librarians are to be taken seriously as scholars, and studies have shown that productivity increases when librarians are given this support. Havener and Stolt found that $53.8 \%$ of the librarians who were working at institutions with research support published during the year 1990, while only $19.5 \%$ published if they were working without institutional support. ${ }^{64}$ The research advisory committee approach described by Auburn University may be the type of program worth considering to boost productivity and share the responsibility of mentoring. ${ }^{65}$

While the lack of association membership compensation and other types of research support may place an expensive burden on the individual professional, librarians continue to debate institutional versus personal responsibilities related to financial obligations for professional development. ${ }^{66}$

If librarians need to negotiate for better support for research, what is the best method? In this study, unionization does seem to confer a strong advantage to librarians in terms of sabbaticals and research funding. Unionization may empower librarians to seek additional benefits such as formalizing research time into job assignments. Very 
little has been written about the possible advantages of unionization for librarians and this is an area that would benefit from additional research.

Additional regional studies and updates of national surveys would be beneficial at this point. To succeed in their research efforts, librarians should be proactive, exploring all financial avenues available to them such as institutional research support and external funding opportunities. Librarians should actively request, and productively use, time for research. The challenge that Payne and Wagner issued back in 1984 still stands, “...now it is time to leave the library walls and exploit all sources available to teaching faculty."67

\section{Notes and References}

1. Lou Helen Devine Sanders, "Faculty Status for Academic Librarians," in Encyclopedia of Library and Information Science, Volume 48, Supplement 11, ed. Allen Kent. New York: Marcel Dekker, Inc, 1991, p. 130.

2. Ibid., p. 134.

3. American Library Association. Association of College and Research Libraries. "Standards for Faculty Status for College and University Librarians," College and Research Libraries News no. 8, (September 1972): 210-212.

4. Bruce R. Kingma and Gillian M. McCombs, "The Opportunity Costs of Faculty Status for Academic Librarians," College and Research Libraries 56, (May 1995): 258-264.

5. W. Michael Havener and Wilbur A. Stolt, "The Professional Development Activities of Academic Librarians: Does Institutional Support Make a Difference?" College and Research Libraries 55, (January 1994): p. 33. 
6. Deborah B. Henry and Tina M. Neville, "Research, Publication, and Service Patterns of Florida Academic Librarians," Journal of Academic Librarianship 30, (November 2004): 435-451.

7. W. Michael Havener and Philip Worrell, "Environmental Factors in Professional Development Activities: Does Type of Academic Library Affiliation Make a Difference?" Library \& Information Science Research 16, (Summer 1994): p. 238.

8. Shelley Arlen and Nedria Santizo, "Administrative Support for Research: A Survey of Library Faculty," Library Administration \& Management 4, (Fall 1990): pp. 208212; Donna Pittman Blomberg and Karen Chapman, "Survey of Travel Support Policies at ARL Libraries," Journal of Academic Librarianship 15, (May 1989): pp. 90-93; John Cosgriff, Donald Kenney, and Gail McMillan, "Support for Publishing at Academic Libraries: How Much Exists?" Journal of Academic Librarianship 16, (May 1990): 94-97; Michael D. Cramer, Travel Policies in ARL Libraries. SPEC Kit 161, U.S.; District of Columbia: Association of Research Libraries, 1990; Thomas G. English, "Librarian Status in the Eighty-Nine U.S. Academic Institutions of the Association of Research Libraries: 1982," College and Research Libraries 44, (May 1983): 199-211; William H. Jesse and Ann E. Mitchell, "Professional Staff Opportunities for Study and Research," College and Research Libraries 29, (March 1968): pp. 87-100; Kingma and McCombs, "The Opportunity Costs of Faculty Status for Academic Librarians," pp. 258-264; Jack E. Pontius, Cordelia W. Swinton, and Frederick J. Van Antwerp, Faculty Status, Research Requirements, and Released Time. U.S.; Pennsylvania: ERIC, 1978; Ronald Rayman and Frank W. Goudy, "Research and Publication Requirements in University Libraries," College and 
Research Libraries 41, (January 1980): 43-48; Teri R. Switzer, comp. Benefits for Professional Staff in ARL Libraries. SPEC Kit 197, U.S.; District of Columbia: Association of Research Libraries, 1993.

9. Anne Carson Cargile, "A Survey of the Academic Status of Librarians in North Carolina's Colleges and Universities," North Carolina Libraries 31, (Winter 1973): pp. 20-22; Della H. Darby and Kimberly C. Weatherford, "Academic Librarian Status and Benefits in Alabama," Alabama Librarian 52, (2002): pp. 13-19; John N. DePew, "Faculty Status in Florida," Florida Libraries 28, (January-February 1978): 1, 4-5; Becky Bolte Gray and Rosalee McReynolds, "A Comparison of Academic Librarians With and Without Faculty Status in the Southeast," College and Research Libraries (July 1983): pp. 283-287; Donald J. Kenney and Gail McMillan, "Librarians in Academic Limbo: Support for Scholarship," Southeastern Librarian 39, (Winter 1989): 139-141; Tamera P. Lee, "The Library Research Committee: It Has the Money and the Time," The Journal of Academic Librarianship 21, (March 1995): 111-115; Steven E. Rogers, "Support for Research and Publishing in Tennessee's Academic Libraries: a Survey of College and University Librarians," Tennessee Librarian 48, (Spring 1996): pp. 35-43; Prabha Sharma, "A Survey of Academic Librarians and Their Opinions Related to Nine-Month Contracts and Academic Status Configurations in Alabama, Georgia, and Mississippi," College and Research Libraries 42, (November 1981): 561-570.

10. Vivian R. Boughter, "Salaries, Work Week, Vacations, Benefits, and Privileges of College Librarians," College and Research Libraries, (March 1958): 126-128. 
11. Cargile, "A Survey of the Academic Status of Librarians in North Carolina's Colleges and Universities," p. 21; Gray and McReynolds, "A Comparison of Academic Librarians With and Without Faculty Status in the Southeast," p. 285; Jesse and Mitchell, "Professional Staff Opportunities for Study and Research," p. 91; Virgil F. Massman, Faculty Status for Librarians, Metuchen, N.J.: Scarecrow Press, 1972, p. 164; Rogers, "Support for Research and Publishing in Tennessee's Academic Libraries," p. 39; Switzer, comp. Benefits for Professional Staff in ARL Libraries. SPEC Kit 197, p. 4; Virginia Vesper and Gloria Kelley, Criteria for Promotion and Tenure for Academic Librarians. CLIP Note \#26, Chicago: American Library Association. Association of College and Research Libraries, 1997, p. 23.

12. Carolyn Gaskell and Allen S. Morrill, Travel, Sabbatical, and Study Leave Policies in College Libraries. CLIP Note \#30, Chicago: American Library Association, 2001, p. 13.

13. Jesse and Mitchell, "Professional Staff Opportunities for Study and Research," p. 97. 14. Arlen and Santizo, "Administrative Support for Research," p. 210; Alexander W. Astin, William S. Korn, and Eric L. Dey, The American College Teacher. National Norms for the 1989-90 HERI Faculty Survey, U.S.; California: Higher Education Research Institute, 1991, p. 11; Paul Berman, Jo-Ann Intili, and Daniel Weiler, Exploring Faculty Development in California Higher Education. Volume II, Findings. Report 88-19, U.S.; California: Publications Office, 1987, p. 71.

15. Paul Berman and Daniel Weiler, Exploring Faculty Development in California Higher Education. Volume I, Executive Summary and Conclusions. Report 88-18, U.S.; California: Publications Office, 1987, p. 11; Monir H. Sharobeam and Keith 
Howard, "Teaching Demands Versus Research Productivity: Faculty Workload in Predominately Undergraduate Institutions," Journal of College Science Teaching 31, (May, 2002): p. 439.

16. Nancy J. Emmick, "Release Time for Professional Development: How Much for Research?" Seattle, Washington, Association of College and Research Libraries, April 4-7, 1984, p.129; Frank William Goudy and Allie Wise Goudy, "The Dilemma of Library Faculty Workload: One Solution," Library Administration \& Management 2, (January 1988): p. 36; Jesse and Mitchell, "Professional Staff Opportunities for Study and Research," p. 95; Rogers, "Support for Research and Publishing in Tennessee's Academic Libraries," p. 41; Sharobeam and Howard, "Teaching Demands Versus Research Productivity,”p. 437.

17. Sharobeam and Howard, "Teaching Demands Versus Research Productivity," p. 440. 18. Massman, Faculty Status for Librarians, p. 178.

19. Carnegie Classifications for Research I and II used in 1994 are included in the 2000 conversion to Carnegie Classifications for Doctoral Research Extensive and Doctoral Research Intensive, two of the categories used for comparisons in this study. See "Shifting Categories: A Comparison of the 1994 and 2000 Classifications," Chronicle of Higher Education (August 11, 2000), Available: http://chronicle.com/free/v46/i49/49a03601.htm. (November 21, 2005).

20. Joan M. Leysen and William K. Black, "Peer Review in Carnegie Research Libraries," College and Research Libraries 59, (November 1998): p. 517.

21. Henry and Neville, "Research, Publication, and Service Patterns of Florida Academic Librarians," p. 441. 
22. Blomberg and Chapman, "Survey of Travel Support Policies at ARL Libraries," p. 92.

23. Cramer, Travel Policies in ARL Libraries. SPEC Kit 161, p. 4.

24. North Dakota Library Association. Executive Board, "NDLA Executive Board Meeting Minutes," North Dakota Library Association, p. 6, Available: http://ndsl.lib.state.nd.us/ndla/31403min.pdf (February 24, 2005); North Carolina Library Association, "SELA Holds Leadership Conference, Selects Charleston as Biennial Site," E-News 3, (April 2001): paragraph 4, Available: http://www.nclaonline.org/e-news/e-newsapr2001.htm (February 24, 2005); American Library Association, "ALA Student Forum. Pratt Institute," American Library Association, (April 2004): paragraph 3, Available: http://www.ala.org/ala/ourassociation/governingdocs/adheadto2010/prattforum.htm (February 24, 2005); John N. Berry, “ALA is a Business!” Library Journal, 130, (February 15, 2005), p. 8; Peter R. Young and Lizbeth J. Bishoff, "If I Were Treasurer--," Library Journal 125, (March 1, 2000): p. 47, Available: http://vnweb.hwwilsonweb.com/hww/jumpstart.jhtml?prod=LIBFT, (February 24, 2005); John N. Berry, "The High Cost of ALA Participation," Library Journal 126, (June 1, 2001): p. 8, Available: http://vnweb.hwwilsonweb.com/hww/jumpstart.jhtml?prod=LIBFT, (February 24, 2005); GraceAnne Andreassi DeCandido, "Money Changes Everything," Wilson Library Bulletin 69, (February 1995): p. 6, Available: http://vnweb.hwwilsonweb.com/hww/jumpstart.jhtml?prod=LIBFT. (February 24, 2005). 
25. Darby and Weatherford, "Academic Librarian Status and Benefits in Alabama," p. 16. 26. Henry and Neville, "Research, Publication, and Service Patterns of Florida Academic Librarians," pp. 435-451.

27. Arlen and Santizo, "Administrative Support for Research" pp. 208, 210; Blomberg and Chapman, "Survey of Travel Support Policies at ARL Libraries," pp. 91-92; "Chronicle Survey: Faculty Members' Views of Trends in their Departments, 1983 to 1984," Chronicle of Higher Education 30, (June 12, 1985): p. 22; Cramer, Travel Policies in ARL Libraries. SPEC Kit 161, pp. 6-8; Darby and Weatherford, "Academic Librarian Status and Benefits in Alabama," pp. 15-17; Gaskell and Morrill, Travel, Sabbatical, and Study Leave Policies in College Libraries. CLIP Note \#30, pp. 26-34; Henry and Neville, "Research, Publication, and Service Patterns of Florida Academic Librarians," p. 447; Joyce Payne and Janet Wagner, "Librarians, Publication, and Tenure," College and Research Libraries 45, (March 1984): pp. 134, 136.

28. Information Today, Inc., American Library Directory, 2004-2005, 57th ed. Vol. 1. Medford, NJ: Information Today, Inc, 2004.

29. Carnegie Classifications were restructured in November 2005. This study uses the 2000 classifications to provide direct comparisons to the author's 2003 survey. Carnegie Foundation, 2000 Carnegie Classification, Available: http://www.carnegiefoundation.org/Classification/CIHE2000/defNotes/Definitions.ht m (September 22, 2005).

30. Henry and Neville, "Research, Publication, and Service Patterns of Florida Academic Librarians," p. 437. 
31. Ibid, p. 438.

32. Darby and Weatherford, "Academic Librarian Status and Benefits in Alabama," p. 16.

33. Massman, Faculty Status for Librarians, p.181.

34. Cargile, "A Survey of the Academic Status of Librarians in North Carolina's Colleges and Universities," pp. 21-22.

35. Lothar Spang and William P. Kane, "Who Speaks for Academic Librarians? Status and Satisfaction Comparisons between Unaffiliated and Unionized Librarians on Scholarship and Governance Issues," College \& Research Libraries 58, (September, 1997): 456.

36. Blomberg and Chapman, "Survey of Travel Support Policies at ARL Libraries," p.91

37. Ibid.

38. Cramer, Travel Policies in ARL Libraries. SPEC Kit 161, p. 4.

39. Ibid, p. 5.

40. Henry and Neville, "Research, Publication, and Service Patterns of Florida Academic Librarians," p. 441.

41. Gray and McReynolds, "A Comparison of Academic Librarians With and Without Faculty Status in the Southeast," p.285.

42. Rogers, "Support for Research and Publishing in Tennessee's Academic Libraries," p.40.

43. Rayman and Goudy, "Research and Publication Requirements in University Libraries," p. 45.

44. DePew, "Faculty Status in Florida," p. 5. 
45. Boughter, "Salaries, Work Week, Vacations, Benefits, and Privileges of College Librarians," p. 128.

46. Vesper, "Criteria for Promotion and Tenure for Academic Librarians. CLIP Note \#26," p.23.

47. Gaskell and Morrill, "Travel, Sabbatical, and Study Leave Policies in College Libraries. CLIP Note \#30,” p.13.

48. Rogers, "Support for Research and Publishing in Tennessee's Academic Libraries," p.39.

49. Renee Nesbitt Anderson, John D'Amicantonio, and Henry J. DuBois, "Labor Unions or Professional Organizations: Which Have Our First Loyalty?" College \& Research Libraries 53, (July, 1992): pp. 334-335.

50. Spang and Kane, "Who Speaks for Academic Librarians?" p. 456.

51. Robert G. Sewell, "Faculty Status and Librarians: The Rationale and the Case of Illinois," College and Research Libraries 44, (May 1983): p. 221.

52. Goudy and Goudy, "The Dilemma of Library Faculty Workload: One Solution," pp. 36-39.

53. Rayman and Goudy, "Research and Publication Requirements in University Libraries," p. 45.

54. DePew, "Faculty Status in Florida," p. 5.

55. Payne and Wagner, "Librarians, Publication, and Tenure," p. 134.

56. Havener and Stolt, "The Professional Development Activities of Academic Librarians," p. 27. 
57. Leysen and Black, "Peer Review in Carnegie Research Libraries," p. 517. Carnegie Research I and II were categories used in the 1994 Carnegie Classification system. These categories were later included in the 2000 Carnegie Classification for Doctoral Research Extensive and Doctoral Research Intensive institutions. "Shifting Categories: A Comparison of the 1994 and 2000 Classifications," Chronicle of Higher Education (August 11, 2000) Available: http://chronicle.com/free/v46/i49/49a03601.htm. (November 21, 2005).

58. Cosgriff, Kenney, and McMillan, "Support for Publishing at Academic Libraries," p. 96.

59. Lee, "The Library Research Committee," pp. 111, 114.

60. Darby and Weatherford, "Academic Librarian Status and Benefits in Alabama," p. 16. 61. Stites, Barbara, Results of Survey: Do Institutions Pay for Staff Dues to FLA? Florida Library Association Discussion List, April 15, 2005 (August 19, 2005).

62. Rogers, "Support for Research and Publishing in Tennessee's Academic Libraries," p. 41.

63. Goudy and Goudy, "The Dilemma of Library Faculty Workload," p.37-38; Sewell, "Faculty Status and Librarians," p.221.

64. Havener and Stolt, "The Professional Development Activities of Academic Librarians," p. 33.

65. Lee, "The Library Research Committee," p. 114.

66. Blomberg and Chapman, "Survey of Travel Support Policies at ARL Libraries," p. 93; Roy Tennant, “Strategies for Keeping Current," Library Journal 128, (September 15, 2003): 28. Available: 
http://vnweb.hwwilsonweb.com/hww/jumpstart.jhtml?recid=0bc05f7a67b1790e856b a0dbde8b0d31e549c9e80e1685423e99282fd23854e8ad9613df5c57a8a7\&fmt=H (November 18, 2005); Jesse and Mitchell, "Professional Staff Opportunities for Study and Research," p.97; Emmick, "Release Time for Professional Development," p.129. 67. Payne and Wagner, "Librarians, Publication, and Tenure," p.138. 


\section{Appendix I: Survey Instrument}

\section{Institution:}

\section{General information}

1. Are most librarians at your institution considered:

O Faculty

Professional staff, not faculty

Other (please describe)

2. Are librarians at your library covered by a union contract?

O Yes

O No

Comments?

3. Are your librarians eligible for:

O Promotion

(defined in this survey as a rank upgrade with pay raise based on quality of professional activities [including research and service] as judged by a committee of peers, campus administrators, or external reviewers)

O Promotion and tenure

(defined in this survey as a permanent employment contract awarded for successful achievements in research, teaching, and service)

Continuing contract

(defined in this survey as a permanent or long-term [multiyear] contract based on professional performance and years of service but not necessarily related to scholarship or publishing achievements)

Continuing contract and promotion

O Not eligible for promotion or tenure

O Other (please describe)

4. If librarians at your institution are eligible for promotion and/or tenure based on publishing and professional service, in your opinion, which statement would be most accurate?

At my institution, promotion and tenure requirements have become less rigorous within the last five years

At my institution, promotion and tenure requirements have become more rigorous within the last five years

At my institution, promotion and tenure requirements have stayed about the same in the last five years

I have no opinion on this matter 
5. Who decides on librarian promotion/tenure at your institution? Please check all that apply:

Library supervisor/director

Peer review committee

Institution-wide review committee

Institutional administration (Provost, President, etc.)

Other (please describe)

Comments?

\section{Travel}

NOTE: for the purposes of the survey, travel will be defined as attendance at professional conferences and workshops for personal professional development, professional association committee meetings, and research presentations (including invited presentations, panel sessions, and poster sessions.) Required administrative attendance as an official representative of the library should not be included in your response.

1. Does your library provide travel support for your librarians to attend professional meetings and conferences for personal professional development?

$\mathrm{O}$ Yes

No (please move to the next section regarding research support, page 4)

2. In your opinion, has travel funding at your library:

$\mathrm{O}$ Increased during the last 5 years

O Decreased during the last 5 years

Stayed fairly constant during the last 5 years

Comments?

3. Who determines how travel funds will be allocated (please check all that apply):

Library Dean/Director or other library administrator

Librarian's direct supervisor

O Library travel committee

Academic Dean or Provost (outside of the library)

O Institutional travel committee

Other (please describe)

4. If travel funding comes from an institutional travel committee does the library have representation on that committee?

O Yes, the library is guaranteed a spot on the institutional travel committee

O Yes, librarians are eligible to be elected to the institutional travel committee

O No

5. Who is eligible for travel funds (please check all that apply):

$\bigcirc \quad$ Full-time library faculty/professional librarians

O Part-time library faculty/professional librarians

Temporary library faculty/professional librarians

O Permanent paraprofessional staff

Part-time paraprofessional staff 
Temporary paraprofessional staff

O Other (please describe)

6. Please rank the following special criteria by priority as they would apply to your institution. Please label each item as:

$\mathrm{H} \quad$ Given high priority in funding decisions

M Considered in funding decisions

L Given low priority in funding decisions

$\mathbf{N} \quad$ Not considered at all in funding decisions

Members of an association attending a national library conference or workshop Members of an association attending a state or regional library conference or workshop

Non-members of an association attending a national library conference or workshop

Non-members of an association attending a state or regional library conference or workshop

Attendance at a non-library association conference or workshop

Committee members attending national library association committee meetings

Committee members attending state or regional library association committee meetings

Committee members attending non-library association committee meeting

Librarians presenting at a national library workshop or conference

Librarians presenting at a state or regional library workshop or conference

Librarians presenting at a non-library association conference or workshop

Please rank the following additional criteria by priority as they would apply to your institution. Please label each item as:

H Given high priority in funding decisions

$M \quad$ Considered in funding decisions

L Given low priority in funding decisions

$\mathbf{N} \quad$ Not considered at all in funding decisions

Length of service at the library

First-come, first-serve basis

Senior librarians (tenured or at associate or full professor level)

Newer librarians (untenured or still eligible for promotion)

Library Administrators (Deans, Directors, or Department Heads)

Other (please describe)

Additional comments regarding criteria for travel funding decisions?

7. How is travel support funded (please check all that apply)

0 Direct line item for travel in library budget

D Discretionary funds from library budget

O Campus travel funds

Endowments

Other (please describe)

8. Does your library have a written policy on travel allocations?

$\begin{array}{ll}\mathrm{O} & \text { Yes } \\ \mathrm{O} & \text { No }\end{array}$


9. What travel expenses are funded (please check all that apply):

$\begin{array}{lll}\text { Hotel } & \text { O Full cost } & \text { O Partial cost } \\ \text { Air transportation } & \text { O Full cost } & \text { O Partial cost } \\ \text { Rental car } & \text { O Full cost } & \text { O Partial cost } \\ \text { Mileage } & \text { O Full cost } & \text { O Partial cost } \\ \text { Conference registration } & \text { O Full cost } & \text { O Partial cost } \\ \text { Meals } & \text { O Full cost } & \text { O Per diem } \\ \text { Other (please describe) } & & \end{array}$

Other (please describe)

Comments?

10. Does your library provide a specific travel allocation for each librarian?

Yes, each librarian receives up to $\$$

$\mathrm{O}$ No per year OR \$ every __ years

11. Does your library provide travel funding for international travel?

Yes, (please describe)

$\mathrm{O}$ No

12. After returning from a conference or workshop, are librarians required to report their findings/information learned to the administration or present to the library staff?

Yes, (please describe)

O No

Additional comments regarding travel support in general?

\section{Research Support}

1. Are librarians at your institution required to undertake formal research/scholarship (professional presentations, published books and/or refereed journal articles) in order to obtain promotion and/or tenure?

$\begin{array}{ll}\mathrm{O} & \text { Yes } \\ \mathrm{O} & \text { No }\end{array}$

2. Are librarians at your library officially assigned a research component as part of their professional job assignment?

Yes

O No

If yes, please indicate the approximate amount of time they would be allocated for research out of their total job assignment.

By rank:

Administrators:

O $1-5 \% \quad$ O $5-10 \%$ O $10-20 \%$ Omore than $20 \%$

Senior librarians (associate and full professors or library equivalents) :

O $1-5 \% \quad$ O $5-10 \% \quad$ O10-20\% Omore than $20 \%$ 
Newer librarians (instructors and assistant professors or library equivalents)

O $1-5 \% \quad 05-10 \% \quad 010-20 \% \quad$ Omore than $20 \%$

Other (please describe):

O $1-5 \% \quad$ O $5-10 \% \quad 20 \% \quad$ Omore than $20 \%$

By specialization:

Technical service librarians:

O $1-5 \% \quad$ O $5-10 \% \quad$ O $10-20 \% \quad$ Omore than $20 \%$

Public service librarians:

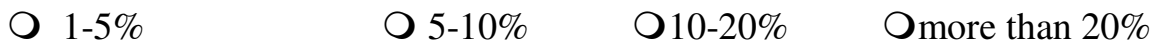

Archivists:

O $1-5 \% \quad$ O $5-10 \% \quad$ O10-20\% Omore than $20 \%$

Other (please describe):

O $1-5 \% \quad$ O $5-10 \% \quad$ O10-20\% Omore than $20 \%$

3. Release time for research:

Are most librarians at your institution allocated regular weekly research time (a set number of hours of release from other professional duties, desk time, and meetings to work on research projects aimed at eventual publication)?

$\mathrm{O}$ Yes

O No

Comments?

If yes, approximately how much time is allocated each week? hours per week

Are librarians at your institutions allowed to work a flexible schedule (work at home or at an off-campus location as part of a normal 35-40 hour work week so they can devote uninterrupted time to research)?

Yes

If yes, approximately how many hours per week is each librarian expected to be present in the library to attend to public service tasks, faculty liaison work, etc? (minimum) hours per week

Are librarians at your institution allowed informal release time of a short duration (1 day to several weeks) on an irregular basis to devote time to research activities?

Yes

O No

4. Are librarians at your institution eligible for sabbaticals?

Sabbaticals are defined in this survey as a lengthy (one semester to one year) professional development leave at full or half pay to enhance a faculty member's career and to increase their value to the institution through opportunities for research-related travel, study, writing, or other experiences of professional value.

$\begin{array}{ll}\mathrm{O} & \text { Yes } \\ \mathrm{O} & \mathrm{No}\end{array}$ 


\section{Research funding:}

Other than travel are librarians at your institution eligible to apply for internal funding to directly support their research?

$\begin{array}{ll}\mathrm{O} & \text { Yes } \\ \mathrm{O} & \mathrm{No}\end{array}$

If internal funding for research is available, how is it funded?

O Direct line for research support in library budget

O Discretional funds from library budget

Librarians may apply for institutional internal research/seed grants

Other (please describe)

6. What additional kinds of support for research are available? (Please check all that apply)

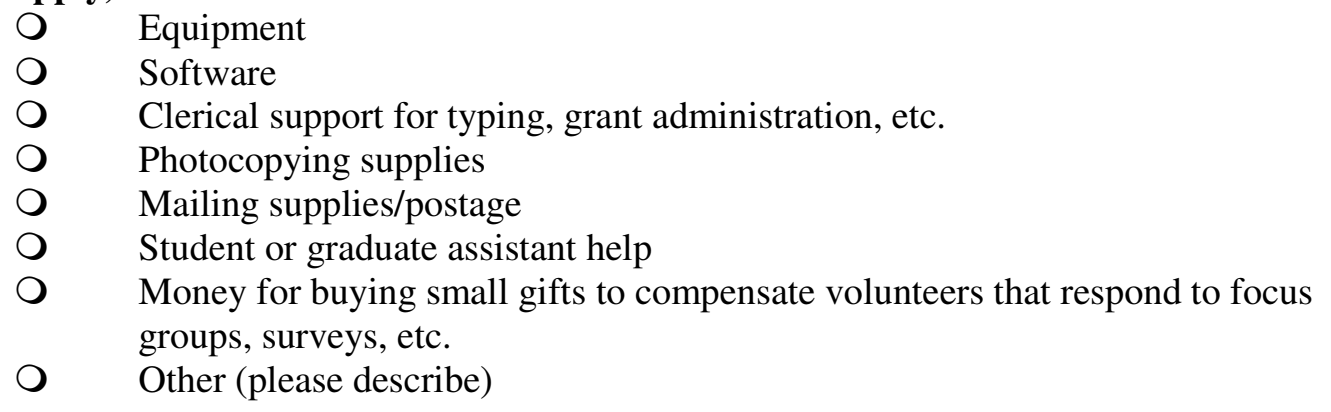

7. Do you provide guidance for library faculty researchers? (Please check all that apply)

Formal mentoring

Informal mentoring

Library research committee to brainstorm ideas, share expertise, etc.

O Personnel with grant-writing/research proposal expertise to help apply for funding, assist with IRB certification, and/or help with submission of manuscripts.

Other (please describe)

No specific guidance provided

If a grant specialist is available, is this a library funded position or are librarians eligible to use institutional grant expertise?

Library funded position

Institutional research office funded position

Other, please describe:

\section{Membership in Professional Associations}

1. Is membership in professional associations considered for library promotion and/or tenure at your institution?

Membership in national associations (ALA, SLA, MLA, etc): 
ORequired OStrongly recommended OConsidered ONot required Membership in the Florida Library Association:

ORequired OStrongly recommended OConsidered ONot required

Membership in regional or local library associations:

ORequired OStrongly recommended OConsidered ONot required

Membership in non-library associations:

ORequired OStrongly recommended OConsidered ONot required

\section{Does your library contribute to personal membership fees for professional}

associations?

Yes, library pays full membership dues, for one or more library-related associations per year

Yes, library pays full membership dues, for one or more non-library professional associations per year

Yes, library pays partial membership dues for library-related associations up to $\$$ ___ per year

Yes, library pays partial membership dues for non-library professional associations up to $\$$ __ per year

No, librarians are personally responsible for any and all professional membership dues.

O Other 